\title{
Body size and extinction risk in Brazilian carnivores
}

\author{
German Forero-Medina ${ }^{1,2,3}$, Marcus Vinícius Vieira ${ }^{1}$, \\ Carlos Eduardo de Viveiros Grelle ${ }^{1}$ \& Paulo Jose Almeida ${ }^{1}$ \\ ${ }^{1}$ Laboratório de Vertebrados, Departamento de Ecologia, Universidade Federal do Rio de Janeiro - UFRJ, \\ CP 68020, CEP 21941-590, Rio de Janeiro, RJ, Brazil \\ ${ }^{2}$ Present address: Nicholas School of the Environment, Duke University, Durham, NC, 27708, USA \\ ${ }^{3}$ Author for correspondence: German Forero-Medina, e-mail: forecroc@yahoo.com
}

FORERO-MEDINA, G., VIEIRA, M.V., GRELLE, C.E.V. \& ALMEIDA, P.J. Body size and extinction risk in Brazilian carnivores. Biota Neotrop., 9(2): http://www.biotaneotropica.org.br/v9n2/en/ abstract?article+bn00509022009.

\begin{abstract}
Because extinctions are not random across taxa, it is important for conservation biologists to identify the traits that make some species more vulnerable. Factors associated with vulnerability include small geographical ranges, low densities, high trophic level, "slow" life histories, body size, and tolerance to altered habitats. In this study we examined the relationship of body size, reproductive output, longevity, and extinction risk for carnivores occurring in Brazil. We used generalized linear models analyses on phylogenetically independent contrasts to test the effect of body size alone, and the combined effect of body size, litter size and longevity on extinction risk. Body size appeared in the two best models according to the selection criteria (AIC), and it was the most plausible bionomic variable associated with extinction risk. Litter size and longevity, bionomic traits previously associated with threat risk of Brazilian carnivores, were implausible. The higher extinction risk for larger species could result from body size influencing vulnerability to different human activities, such as killing, habitat destruction and fragmentation, and the small size of natural reserves.
\end{abstract}

Keywords: carnivores, independent contrasts, longevity, reproductive output, South America, vulnerability to extinction.

FORERO-MEDINA, G., VIEIRA, M.V., GRELLE, C.E.V. \& ALMEIDA, P.J. Tamaño corporal como factor de amenaza en carnívoros brasileros. Biota Neotrop., 9(2): http://www.biotaneotropica.org.br/v9n2/es/ abstract?article+bn00509022009.

Resumen: Debido a que las extinciones no son aleatorias a través de los diferentes taxa, es importante para los biólogos de la conservación identificar las características que hacen a algunas especies más vulnerables. Los factores asociados con la vulnerabilidad incluyen distribuciones geográficas pequeñas, densidades poblacionales bajas, niveles tróficos altos, historias de vida "lentas", tamaño del cuerpo, y tolerancia a habitats alterados. En este estudio examinamos la relación del tamaño corporal, el potencial reproductivo y la longevidad con el riesgo de extinción para los carnívoros brasileros. Realizamos análisis de modelos lineares generalizados con contrastes filogenéticamente independientes para probar el efecto del tamaño corporal solo, y el efecto combinado del tamaño corporal, el tamaño de la camada y la longevidad sobre el riesgo de extinción. El tamaño del cuerpo apareció en los dos mejores modelos de acuerdo con el criterio de selección (AIC) y es la variable bionómica más plausible afectando el riesgo de extinción. El tamaño de la prole y longevidad, otras variables bionómicas que han presentado tal efecto en otros estudios, fueron implausibles. La mayor probabilidad de amenaza para las especies grandes puede deberse a que el tamaño del cuerpo afecta la vulnerabilidad a diferentes actividades humanas como la caza, la destrucción y fragmentación del hábitat, y al tamaño reducido de la mayoría de áreas protegidas.

Palabras clave: carnívoros, contrastes filogenéticos, longevidad, potencial reproductivo, Suramérica, vulnerabilidad a la extinción. 


\section{Introduction}

Conservation biologists deal with issues such as which populations or species are most vulnerable to extinction, which could be affected by different management plans, and ultimately the process that committed species with extinction (Reynolds 2003). Because it is almost impossible to study populations of every living species, it is of great importance to understand the biology of vulnerability, in order to predict which species could be more vulnerable to extinction (Reynolds 2003). Extinctions are not random across taxa (McKinney 1997, Purvis et al. 2000a, Johnson et al. 2002), hence increasing interest has been drawn to identify traits that make species more vulnerable. A range of factors were associated with vulnerability to extinction: small geographical ranges and low densities (Grelle et al. 1999, Purvis et al. 2000b), high trophic level (Crooks \& Soulé 1999, Davies et al. 2000), relatively "slow" life histories such as small litter size and long gestation (Brown 1995, Purvis et al. 2000b), complex social structures (Courchamp et al. 1999), tolerance to modified habitats or matrix in a landscape (Laurance 1991, Castro \& Fernandez 2004), and body size (McKinney 1997, Cardillo \& Bromham 2001, Johnson et al. 2002, Grelle et al. 2006).

Hypotheses associating those traits to vulnerability to extinction are widespread in early and recent scientific literature (see McKinney 1997 and references therein) but some of them appear to apply only for some groups or scales of study (Cardillo \& Bromham 2001, Purvis et al. 2000b). Statistical tests of differences in extinction proneness across scales or taxa are not simple because of incomplete information on the biology and conservation status of many species, - especially in the tropics - and because of the interrelationship among variables (McKinney 1997, Purvis et al. 2000b). Another important fact that must be considered is that taxa are not statistically independent data points because they share common ancestors (Felsenstein 1985, Harvey \& Pagel 1991), hence comparative methods and multivariate tests are necessary (McKinney 1997, Purvis et al. 2000b, Cardillo 2003).

The direct relation of body size to extinction risk has been controversial. Although some studies have found a strong relation (McKinney 1997, Johnson et al. 2002, Cardillo \& Bromham 2001, Grelle et al. 2006), others have argued that these relations are not direct, and that they link body size to extinction risk via correlation with other demographic variables (Henle et al. 2004). Besides, the ambiguous results of the relation could result from the association of body size with variables that have opposed correlations to extinction risk, such as population abundance and population fluctuation (Henle et al. 2004). Recent studies have shown that at least for mammals, on a broad scale body size relates to extinction proneness, and that bigger species are affected by both intrinsic and environmental factors (Cardillo et al. 2005).

In this study we examine the relationship of body size (measured as body mass), reproductive output, longevity and extinction risk for carnivores that occur in Brazil. Carnivores have the third highest number of threatened species in Brazil, only after primates and rodents (Grelle et al. 2006). Their main threat is the destruction or disturbance of natural habitats in the Atlantic Forest, the bush savanna of central Brazil (Cerrado), and the semiarid thorn scrub of the northeast (Caatinga) (Machado et al. 2005). Other threats include hunting and road killings (Machado et al. 2005). Grelle (2006) studied biological traits associated with extinction risk in Brazilian mammals and observed a strong effect of body size on vulnerability, but phylogenetic comparative methods were not used. Non-phylogenetic analyses inflate degrees of freedom for statistical tests, frequently detecting associations that disappear when statistical independence is controlled for (Purvis et al. 2000b). Here we use a comparative method to test the relationship between body size and vulnerability, including other life history attributes commonly associated with extinction risk, such as litter size and longevity. We also discuss the possible influence of other biological and anthropogenic factors on the extinction risk of Brazilian carnivores.

\section{Materials and Methods}

We compiled the list of Brazilian carnivores from Fonseca et al. (1996), and we determined the vulnerability of each species based on the Lista da Fauna Brasileira Ameaçada de Extinção (Machado et al. 2005) (Table 1). This is a reliable list of threatened species in Brazil because it uses the same criteria and levels of threat as the IUCN, and benefits from scientific knowledge generated by Brazilian researchers such as unpublished theses, dissertations, reports, papers published in local journals, and personal field experience (Costa et al. 2005). Because all the threatened carnivore species belonged to the same category (Vulnerable), we assigned each of the species occurring in Brazil to one of two levels of extinction risk, threatened (1) or not threatened (0). This scale of extinction risk is ranked, not categorical, as similarly used by Cardillo \& Bromham (2001), Cardillo (2003), and Purvis et al. (2000a,b). Mean body mass (both males and females) was used as a descriptive variable of body size, and data for all species was compiled from Fonseca et al. (1996). We compiled litter size data from Eisenberg (1989), Redford \& Eisenberg (1992), Nowak (1991) and Fonseca et al. (1994). We used arithmetic means

Table 1. Mean body size (here expressed as body mass), litter size, longevity and threat level for Brazilian carnivores.

Tabla 1. Tamaño del cuerpo (expresado como peso), tamaño de la camada, longevidad y nivel de amenaza para los carnívoros brasileros.

\begin{tabular}{|c|c|c|c|c|}
\hline Species & $\begin{array}{c}\text { Body } \\
\text { size }(g)\end{array}$ & $\begin{array}{c}\text { Litter } \\
\text { size }\end{array}$ & $\begin{array}{c}\text { Longevity } \\
\text { (years) }\end{array}$ & $\begin{array}{l}\text { Threat } \\
\text { Level* }^{*}\end{array}$ \\
\hline Atelocynus microtis & 7750 & 3.6 & 12 & 0 \\
\hline Chrysocyon brachyurus & 22000 & 2.47 & 16.8 & 1 \\
\hline Conepatus chinga & 1750 & 3.5 & 10 & 0 \\
\hline Conepatus semistriatus & 2400 & 4.5 & 10 & 0 \\
\hline Cerdocyon thous & 6500 & 4.5 & 12.7 & 0 \\
\hline Eira barbara & 4850 & 2 & 22.3 & 0 \\
\hline Galictis cuja & 1580 & 3 & 10.2 & 0 \\
\hline Galictis vittata & 1750 & 2 & 12.5 & 0 \\
\hline Herpailurus yaguarondi & 5000 & 2 & 18.6 & 0 \\
\hline Lontra longicaudis & 5800 & 2.5 & 27 & 0 \\
\hline Leopardus pardalis & 10000 & 3 & 28.2 & 1 \\
\hline Leopardus tigrinus & 2250 & 3 & 21.9 & 1 \\
\hline Leopardus wiedii & 3220 & 1.5 & 24 & 1 \\
\hline Mustela africana & 220 & - & - & 0 \\
\hline Nasua nasua & 5100 & 3 & 23.7 & 0 \\
\hline Oncifelis colocolo & 2950 & 2 & 19.6 & 1 \\
\hline Leopardus geoffroyi & 3590 & 3 & 23 & 0 \\
\hline Pteronura brasiliensis & 29000 & 3 & 17.3 & 1 \\
\hline Procyon cancrivorus & 5400 & 3 & 19 & 0 \\
\hline Puma concolor & 74500 & 2 & 23.8 & 1 \\
\hline Potos flavus & 2600 & 1 & 38.4 & 0 \\
\hline Pseudalopex gymnocercus & 4400 & 4 & 13.7 & 0 \\
\hline Panthera onca & 94500 & 2.5 & 28 & 1 \\
\hline Pseudalopex vetulus & 4000 & 3 & 12.6 & 0 \\
\hline Speothos venaticus & 6000 & 3.8 & 14.1 & 1 \\
\hline
\end{tabular}

*1: threatened; 0 : not threatened.

*1: amenazado; 0: no amenazado. 
when many estimates were obtained for the same species. Maximum longevity data was compiled from AnAge online database (http:// genomics.senescence.info/species/).

The effect of body size, litter size, and longevity on extinction risk was translated in eight linear models differing in the number of independent variables: one null model with no effect of the independent variables, three with a single independent variable, three with two independent variables, and one with three independent variables (Table 2). However, original variables had to be log-transformed to reduce the dominant influence of large species, and further transformed in phylogenetically independent contrasts, PIC, which control for non-independence that arises when species are part of a hierarchically structured phylogeny (Felsenstein 1985). PICs have expected mean value of " 0 " (zero), hence the expected value of the intercept is also zero, and all models should be forced through the origin (Harvey \& Pagel 1991). PICs are also standardized for divergence time since cladogenesis because of the gradual mode of evolution assumed by the method (Felsenstein 1985). Appropriate standardization of PICs was checked plotting the absolute value of each PICs versus its measure of divergence time (Garland et al. 1992). Although the index of extinction risk (threat level) itself does not evolve along phylogenies, it is closely associated with biological variables that do, making it necessary to use analyses that control for phylogeny to ensure statistical independence of data points (Purvis et al. 2005). The phylogeny for Brazilian carnivores (Figure 1) was based on the complete phylogeny of the extant Carnivora by Bininda-Emonds et al. (1999), and contrasts were calculated using COMPARE 4.6b (Martins 2004). Some of the IUCN criteria include variables that can be correlated with the traits

Table 2. Model selection statistics for the eight linear models relating phylogenetically independent contrasts (PICs) of life history variables on extinction risk. $\mathrm{AIC}_{\mathrm{c}}=$ Akaike Information Criteria corrected for small samples, $\mathrm{K}=$ number of parameters, $\Delta_{\mathrm{i}}=$ difference between AIC $\mathrm{c}_{\mathrm{c}}$ a model and the model of lowest $\mathrm{AIC}_{\mathrm{c}}$ (best fit model), $\mathrm{w}_{\mathrm{i}}=$ weight of evidence favoring a model. Parameter estimates are shown only for the three models selected as plausible models.

Tabla 2. Resultados de la selección de modelos para los ocho modelos lineares relacionando los contrastes filogenéticamente independientes de características de historia de vida con el riesgo a la extinción. $\mathrm{AIC}_{\mathrm{c}}=$ Criterio de Información Akaike para muestras pequeñas, $\mathrm{K}=$ numero de parámetros, $\Delta \mathrm{i}=$ diferencia entre el AIC del modelo y el modelo con el menor AIC, wi = peso favoreciendo un modelo. Los parámetros estimados son mostrados solamente para los tres modelos seleccionados como plausibles.

\begin{tabular}{|c|c|c|c|c|c|c|c|}
\hline \multirow[t]{2}{*}{ Model } & \multirow[t]{2}{*}{ Independent Variables (PICs) } & \multirow[t]{2}{*}{$K$} & \multirow[t]{2}{*}{ AICc } & \multirow{2}{*}{$\Delta_{i}$} & \multirow{2}{*}{$\mathbf{w}_{\mathrm{i}}$} & \multicolumn{2}{|c|}{ Parameter estimates } \\
\hline & & & & & & Body mass & Litter size \\
\hline 1 & Body mass & 3 & -16.921 & 0.000 & 0.305 & 0.150 & - \\
\hline 2 & Body mass + litter size & 4 & -16.681 & 0.240 & 0.271 & 0.225 & -0.278 \\
\hline 3 & Constant $=0$ only & 2 & -15.257 & 1.664 & 0.133 & - & - \\
\hline 4 & Body mass + longevity & 4 & -14.565 & 2.356 & 0.094 & - & - \\
\hline 5 & Body mass + litter size + longevity & 5 & -14.330 & 2.591 & 0.084 & - & - \\
\hline 6 & Longevity & 3 & -13.555 & 3.366 & 0.057 & - & - \\
\hline 7 & Litter size & 3 & -12.868 & 4.053 & 0.040 & - & - \\
\hline 8 & Litter size + longevity & 4 & -11.000 & 5.921 & 0.016 & - & - \\
\hline
\end{tabular}

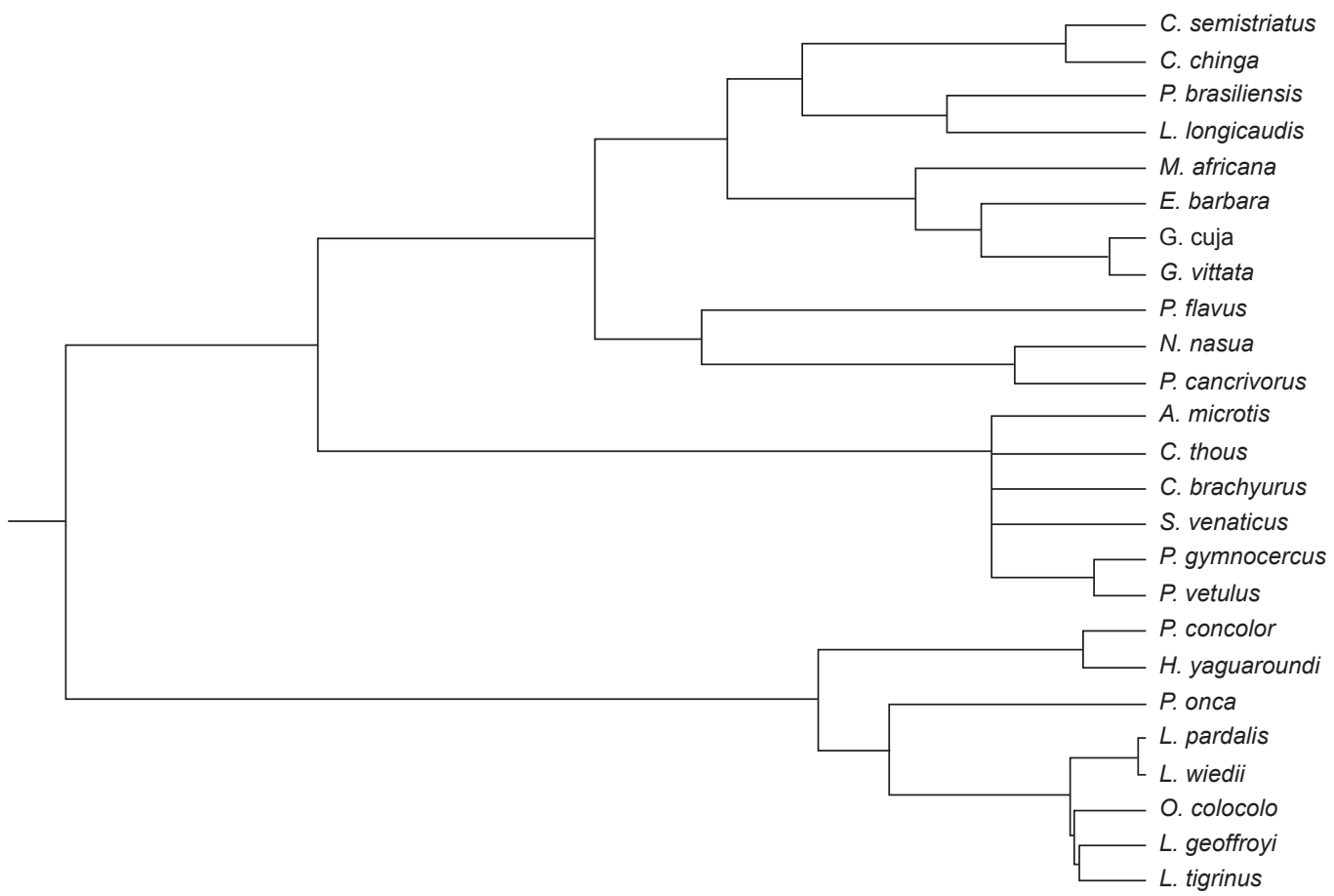

Figure 1. Phylogeny of Brazilian carnivores based on the complete phylogeny of the extant Carnivora by Bininda-Emonds et al. (1999).

Figura 1. Filogenia de los carnívoros brasileros basada en la filogenia completa de los carnívoros realizada por Bininda-Emonds et al. (1999). 
to be analyzed, generating circularity (Purvis et al. 2000b). However, this was not a problem because all threatened species in this study were listed under criteria A3 and A4 (recent or projected decline in population), which are based only on population estimates, hence unrelated to the traits considered here in. Analyses were conducted including all carnivore species except Mustela africana (Desmarest 1818), for which the studied traits are unknown.

The plausibility of the eight linear models considering the data was compared with the Akaike Information Criteria corrected for small samples - AICc - and derived statistics (Burnham \& Anderson 2002). The smaller the value of AICc, the less information a model loses relative to an incommensurable reality (Burnham \& Anderson 2002). However, the value of AICc is relative to the other models in the set, hence the first derived statistic was the AICc difference, $\Delta_{\mathrm{i}}$, the difference between a given model and the most likely model of the set. Models with $\Delta_{\mathrm{i}}>4$ are considered to have "considerably less empirical support from the data" than models with $\Delta_{i}<4$ (Burnham \& Anderson 2002: 70-71). The second statistic was the Akaike weight, $\mathrm{w}_{\mathrm{i}}$, which estimates the relative likelihood of a model given the data and the set of models analyzed, namely, the weight of evidence in favor of a model (Burnham \& Anderson 2002: 75). The values of $\mathrm{w}_{\mathrm{i}}$ are scaled to make their sum over the models add to 1 .

\section{Results and Discussion}

Akaike weights, $w_{\mathrm{i}}$, of the three most plausible models add up to 0.71 (Table 2), hence $71 \%$ of the weight of evidence favors these three models (with $\Delta_{\mathrm{i}}<2$ ). Models 6, 7, 8 had $w_{\mathrm{i}}<0.065$ hence were disregarded. Body size was present in two of the three most plausible models, whereas longevity was present only in the fourth ranked model (Table 2). Thus, body size was a more plausible predictor of extinction risk in Brazilian carnivores than other bionomic variables generally found to have a strong influence in vulnerability. Although a null model of no effect of the independent variables on threat risk cannot be completely disregarded $\left(\Delta_{i}<2\right)$, body size was the only variable present in the model of lowest AICc and conversely highest $\mathrm{w}_{\mathrm{i}}$.

Therefore, body size appeared as the most plausible correlate of extinction risk for Brazilian carnivores, with larger species having a higher risk of extinction. It is clear that this relation is reduced by the value corresponding to the ancestral of Leopardus geoffroyiLeopardus tigrinus (negative outlier in Figure 2). This low value

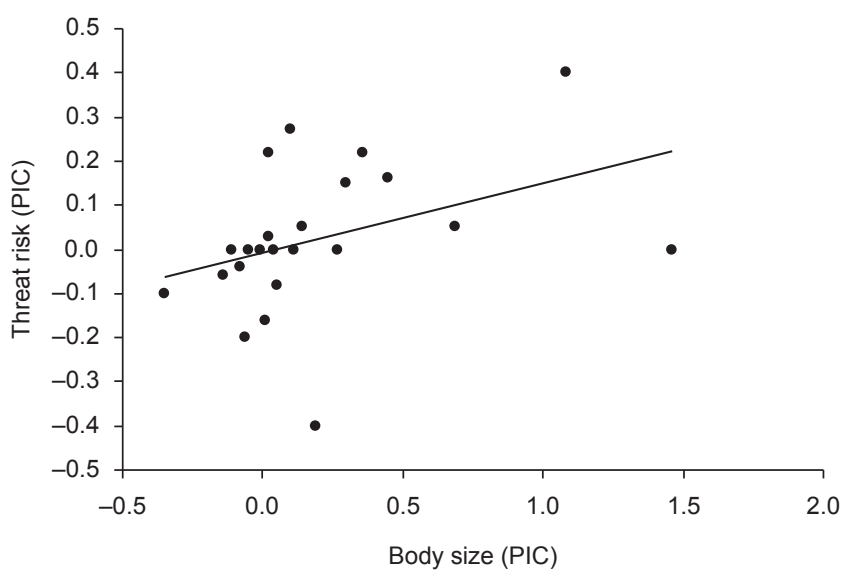

Figure 2. Relationship between the phylogenetically independent contrasts (PICs) of body size and extinction risk for Brazilian carnivores (both axis are PICs).

Figura 2. Relación entre los contrastes filogenéticamente independientes (PIC) del tamaño del cuerpo y riesgo a la extinción en los carnívoros brasileros (los dos ejes corresponden a PIC). results from the fact that L. geoffroyi (d'Orbigny and Gervais 1844) is not considered threatened while L. tigrinus (Schreber 1775), its sister taxon in the phylogeny, with similar weight is. However, although $L$. geoffroyi is not considered threatened, there is a declining trend in its populations due to degradation of its habitat and prey base, and it may classify as vulnerable if these trends continue or more information on its status and range were available (IUCN 2006). Were this species considered as vulnerable (as it might be) the independent contrast would yield a higher value, thus increasing the plausibility of the relationship with body size.

Purvis et al. (2000b) conducted phylogenetic analysis for contemporary carnivores and found that body size was not correlated with extinction risk when other variables were controlled, and that small geographic range, "slow" life history, population density, and trophic level were the best predictor variables. For Brazilian carnivores, the opposite trend was observed, in agreement with previous studies which have found this correlation for Brazilian and Australian species (Cardillo \& Bromham 2001, Grelle et al. 2006).

Other traits usually correlated with body size do not show an effect on extinction risk for Brazilian carnivores. Litter size, our measure of reproductive output, was neither correlated with body size nor extinction risk. Neither was longevity, a trait usually associated with "slow" life histories. A spurious association between body size and extinction risk could also arise if the representation of body sizes differed between areas that also differed in rates of extinctions or human pressures (Cardillo \& Bromham 2001). This would happen, for instance, if threatened carnivores in Brazil belonged mostly to the Atlantic Forest and species from this domain were larger than species from other domain. This is not the case because none of the threatened species is endemic to a single domain, all occurring in at least three different domains.

For large carnivores such as Panthera onca (Linnaeus 1758) and Puma concolor (Linnaeus 1771) in Brazil, body size could influence vulnerability to human activities such as hunting and killing, or habitat destruction. In fact, hunting and killing appear as the main threat to these species in Brazil, because they often attack livestock, particularly in the Pantanal region (Costa et al. 2005). Another fact that can affect these species is the large areas they need in order to have viable populations and disperse. In cougars, for example, nearly all male offspring disperse from their maternal home range (Weaver et al. 1996), and dispersal is crucial because it is responsible for replacement of nearly all males and some females in local populations (Weaver et al. 1996). As dispersal distances for large carnivores can be extensive, they are less protected in small reserves than species with small dispersal distances. Thus, an interaction between body size, natural history traits and the size of protected areas may contribute to the high vulnerability of larger Brazilian carnivores.

Our results suggest body size as more important than litter size and longevity to predict threat risk, which agrees with studies of other carnivores (Cardillo \& Bromham 2001, Johnson et al. 2002). However, the effect of body size on extinction proneness may depend on the range of sizes and context of the species. For Brazilian carnivores, body size appears as a threat factor because of the interaction between life history traits associated with a large body size and the size of protected areas.

\section{Acknowledgements}

We kindly thank N. Olifiers for reviewing the text, two anonymous referees whose comments were valuable for improving the analyses and the text, and the financing institutions CAPES, CNPq and PPGE-UFRJ. 


\section{References}

BININDA-EMMONDS, O.R.P., GITTLEMAN, J.L. \& PURVIS, A 1999. Building large trees by combining phylogenetic information: a complete phylogeny of the extant Carnivora (Mammalia). Biol. rev. 74(2):143-175.

BROWN, J.H. 1995. Macroecology. The University of Chicago Press, Chicago.

BURNHAM, K.P. \& ANDERSON, D.R. 2002. Model selection and multimodel inference: a practical information-theoretic approach. Springer-Verlag, Heidelberg.

CARDILLO, M. \& BROMHAM, L. 2001. Body size and risk of extinction in Australian mammals. Conserv. biol. 15(5):1433-1440.

CARDILLO, M. 2003. Biological determinants of extinction risk: why are smaller species less vulnerable? Anim. conserv. 6(1):63-69.

CARDILlO, M., MACE, G.M., JONES, K.E., BIELBY, J., BININDAEMONDS, O.R.P., SECHREST, W., ORME, D.L. \& PURVIS, A. 2005. Multiple causes of high extinction risk in large mammal species. Disponível em: <www.sciencemag.org >. (último acesso em 19/11/2007)

CASTRO, E.B. \& FERNANDEZ, F.A.S. 2004. Determinants of differential extinction vulnerabilities of small mammals in Atlantic Forest fragments in Brazil. Biol. conser. 119(1):73-80.

COSTA, L., LEITE, Y.L., MENDES, S. \& DITCHFIELD, A.D. 2005. Mammal Conservation in Brazil. Conserv. biol. 19(3):672-679.

COURCHAMP, F., CLUTTON-BROCK, T.H. \& GRENFELL, B. 1999. Inverse density dependence and the Allee effect. Trends in Ecology and Evolution, 14(10):405-410.

CROOKS, K.R. \& SOULÉ, M.E. 1999. Mesopredator release and avifaunal extinctions in a fragmented system. Nature, 400(6744):563-566.

DAVIES, K.F., MARGULES, C.R. \& LAWRENCE, J.F. 2000. Which traits of species predict population declines in experimental forest fragments? Ecology, 81(5):1450-1461.

EISENBERG, J.F. 1989. Mammals of the Neotropics. The Northern Neotropics, Volume 1. Panama, Colombia, Venezuela, Guyana, Suriname, French Guiana. The University of Chicago Press, Chicago.

FELSENSTEIN, J. 1985. Phylogenies and the comparative method. American Naturalist, 125(1):1-15.

FONSECA, G.A.B., HERRMANN, G., LEITE, Y.L.R., MITTERMEIER, R.A., RYLANDS, A.B. \& PATTON, J.L. 1996. Lista Anotada dos Mamíferos do Brasil. Occasional Papers on Conservation Biology, 4:1-38

FONSECA, G.A.B., RYLANDS, A.B., COSTA, C.M.R., MACHADO, R.B \& LEITE, Y. (Eds.). 1994. Livro vermelho dos mamíferos brasileiros ameaçados de extinção. Fundação Biodiversitas, Belo Horizonte.

GARLAND, Jr., T., HARVEY, P.H. \& IVES, A.R. 1992. Procedures for the analysis of comparative data using phylogenetically independent contrasts. Systematic biol. 41(1):18-32.

GRELLE, C.E., PAGLIA, A.P. \& SILVA, H.S. 2006. Análise dos fatores de ameaça de Extinção: estudo de caso com os mamíferos brasileiros. In Biologia da conservação: essências (C.F. Rocha, H. Bergallo, M. Van Sluys \& M.A. Alves, eds.). Rima Editora, São Carlos, p. 385-398.
GRELLE, C.E., FONSECA, G.A.B., FONSECA, M.P. \& COSTA, L.P. 1999 The question of scale in threat analysis: a case study with Brazilian mammals. Anim. conserv. 2(2):149-152

HARVEY, P.H. \& PAGEL, M.D. 1991. The comparative method in evolutionary biology. 1 ed. Oxford University Press, Oxford.

HENLE, K., DAVIES, K.F., KLEYER, M., MARGULES, C. \& SETTELE, J. 2004. Predictors of species sensitivity to fragmentation. Biodiversity conserv. 13(1):207-251.

IUCN. 2006. 2006 IUCN Red List of Threatened Species. Disponível em: $<$ www.iucnredlist.org > (último acesso em 29/01/2007).

JOHNSON, C.N., DELEAN, S. \& BALMFORD, A. 2002. Phylogeny and the selectivity of extinction in Australian marsupials. Anim. conserv. $5(2): 135-142$.

LAURANCE, W.F. 1991. Ecological correlates of extinction proneness in Australian Tropical Rain Forest Mammals. Conserv. biol. 5(1):79-89.

MACHADO, A.B., MARTINS, C. \& DRUMMOND, G. (Eds.). 2005. Lista da fauna brasileira ameaçada de extinção: incluindo as listas das espécies quase ameaçadas e deficientes em dados. Fundação Biodiversitas, Belo Horizonte.

MARTINS, E.P. 2004. COMPARE, version 4.6b. Computer programs for the statistical analysis of comparative data. Department of Biology, Indiana University, Bloomington, Indiana. Disponível em: <http://compare.bio. indiana.edu/>

McKINNEY, M.L. 1997. Extinction vulnerability and selectivity: combining ecological and paleontological views. Ann. rev. syst. 28:495-516.

NOWAK, R.M. 1991. Walker's mammals of the world. 5 ed. The John Hopkins University Press, Baltimore and London.

PURVIS, A., AGAPOW, P.M., GITTLEMAN, J.L. \& MACE, G.M. 2000a. Nonrandom extinction and the loss of evolutionary history. Science, 288:328-330.

PURVIS, A., GITTLEMAN, J.L., COWLISHAW, G. \& MACE, G.M. 2000b. Predicting extinction risk in declining species. Proc. R. Soc. Lond. B. Biol. sci. 267(7):1947-1952.

PURVIS, A., CARDillo, M., GRENYER, R. \& COLLEN, B. 2005 Correlates o extinction risk: phylogeny, biology, threat and scale. In Phylogeny and Conservation (A. Purvis, J. Gittleman \& T. Brooks, eds.). Cambridge University Press, Cambridge, 431 p.

REDFORD, K.H. \& EISENBERG, J.F. 1992. Mammals of the neotropics, the southern cone. V. 2, Chile, Argentina, Uruguay, Paraguay. The University of Chicago Press, Chicago.

REYNOLDS, J.D. 2003. Life histories and extinction risk. In Macroecology: Concepts and Consequences (T.M. Blackburn \& K.J. Gaston, eds.). Blackwell Publishing, Oxford, p. 195-217.

WEAVER, J.L., PAQUET, P.C. \& RUGGIERO, L.F. 1996. Resilience and conservation of large carnivores on the Rocky Mountains. Conserv. biol. 10(4):964-976.

Received 21/02/08

Revised 16/03/09

Accepted 01/04/09 